\title{
PENYELUNDUPAN HUKUM PERKAWINAN BEDA AGAMA DI INDONESIA
}

\author{
Prasetyo Ade Witoko \\ E-mail : prasetyoadew22@gmail.com \\ Mahasiswa Fakultas Hukum Universitas Sebelas Maret Surakarta \\ Ambar Budhisulistyawati \\ E-mail : ambarbudhi@gmail.com \\ Dosen Fakultas Hukum Universitas Sebelas Maret Surakarta
}

\begin{abstract}
This article aims to find out about interfaith marriage arrangements carried out through legal smuggling in Indonesia. This study is a descriptive doctrinal legal research. Data sources from this article are in the form of primary legal material and secondary legal material. The technique of collecting legal material in this article is the library study technique. The approach in this research is the legislative approach. The result of the article is that marriage according to the Marriage Law is a marriage carried out according to each religion and belief. So that marriage is considered valid if according to the religion and beliefs of each prospective husband and wife is also valid. Every religion cannot authorize interfaith marriages, because all religions want their followers to marry the same religion, it can be concluded that interfaith marriages are not legal, because they are not in accordance with the contents of the Marriage Law, namely marriage is valid if carried out according to each religion-one, then avoidance of the law that should apply or can be said to be an act of legal smuggling.
\end{abstract}

Keywords: Marriage; Different Religion Marriage; Law Smuggling

\begin{abstract}
Abstrak
Artikel ini bertujuan untuk mengetahui mengenai pengaturan perkawinan beda agama yang dilakukan melalui penyelundupan hukum di Indonesia. Penelitian ini adalah penelitian hukum doktrinal bersifat deskriptif. Sumber data dari artikel ini yaitu berupa bahan hukum primer dan bahan hukum sekunder. Tehnik pengumpulan bahan hukum dalam artikel ini adalah tehnik studi kepustakaan. Pendekatan dalam penilitian ini adalah pendekatan perundang-undangan. Hasil artikel yaitu perkawinan menurut Undang-Undang Perkawinan adalah perkawinan yang dilaksanakan menurut agama dan kepercayaan masing-masing. Sehingga perkawinan dianggap sah jika menurut agama dan kepercayaan masing-masing calon suami istri tersebut juga sah. Setiap agama tidak bisa mengesahkan perkawinan beda agama, karena semua agama menginginkan umatnya untuk menikah dengan yang seagama, maka dapat disimpulkan bahwa perkawinan beda agama tidak sah, karena tidak sesuai dengan isi Undang-Undang Perkawinan yaitu perkawinan adalah sah apabila dilaksanakan menurut agama dan kepercayaan masing-masing, maka dilakukan penghindaran terhadap hukum yang seharusnya berlaku atau dapat dikatakan sebagai tindakan penyelundupan hukum.
\end{abstract}

Kata Kunci : Perkawinan; Perkawinan Beda Agama; Penyelundupan Hukum 


\section{A. Pendahuluan}

Perkawinan merupakan suatu peristiwa yang penting dalam hidup manusia, karena perkawinan menyatukan pribadi kedua calon suami istri, tidak hanya itu tetapi juga menyangkut urusan keluarga dan masyarakat. Perkawinan pada umumnya dianggap sebagai suatu hal yang suci karena berhubungan antara kaedah-kaedah perkawinan dan kaedahkaedah agama. Dalam perkawinan harus ada norma hukum dan tata tertib yang mengaturnya. Kompleksitas masalah perkawinan, yang antara lain perkawinan campuran, kawin kontrak, dan perkawinan beda agama. Nikah beda agama adalah perkawinan antara dua orang, pria dan wanita yang tunduk pada hukum agama yang berlainan. Terhadap perkawinan beda agama, pada dasarnya hukum perkawinan di Indonesia tidak mengatur secara khusus mengenai perkawinan pasangan beda agama sehingga ada kekosongan hukum. Mengenai sahnya perkawinan adalah perkawinan yang dilakukan sesuai agama dan kepercayaannya sebagaimana diatur dalam Pasal 2 ayat (1) Undang-Undang Perkawinan. Hal ini berarti Undang-Undang Perkawinan menyerahkan pada ajaran dari agama masing-masing (Rusli dan R. Tama, 1986:11).

Seluruh agama yang diakui di Indonesia tidak membolehkan adanya perkawinan yang dilakukan jika kedua calon beda agama. Misalnya menurut agama Kristen perkawinan beda agama itu tidak sah, karena tidak dilakukan menurut aturan agama Kristen dan tidak sesuai dengan syarat yang ditentukan dalam perkawinan. Agama Islam melarang keras setiap orang untuk melaksanakan perkawinan campuran karena tidak sesuai dengan aturan agama Islam. Tidak sah hukumnya perkawinan yang dilakukan oleh sepasang orang yang berbeda agama alam pandangan agama Islam (Rusli dan R. Tama, 1986:11).

Guru Besar Hukum Perdata Universitas Indonesia Prof. Wahyono Darmabrata, menjabarkan ada empat cara yang populer ditempuh pasangan beda agama agar pernikahannya dapat dilangsungkan yang diakui oleh negara dan masyarakat, yaitu : meminta penetapan pengadilan, perkawinan dilakukan menurut masing-masing agama, misalnya pria beragama Hindu menikah dengan wanita beragama Islam dilakukan di tempat kediaman calon istri yang beragama Islam dan memenuhi keinginan keluarga istri yang beragama Islam dengan mengucapkan dua kalimat Syahadat, tapi kemuduan dilakukan lagi perkawinan menurut tata cara agama Hindu bertempat di keluarga pria yang beragama Hindu (Wahyono Darmabrata, 2004:6). Cara tersebut merupakan penyelundupan hukum. Penyelundupan hukum atau fraus Legis (latin) adalah suatu perbuatan yang dilakukan seseorang guna mendapatkan akibat hukum tertentu (hak) berdasarkan hukum asing yang apabila didasarkan dengan hukum nasionalnya akibat hukum tersebut tidak akan terwujud.

Berdasarkan uraian di atas maka dalam artikel ini akan dibahas penyelundupan hukum perkawinan beda agama di Indonesia.

\section{B. Metode Penelitian}

Jenis penelitian dalam artikel hukum ini adalah penelitian hukum normatif atau doktrinal. Penelitian ini sebagai ilmu yang bersifat deskriptif analisis, yaitu dengan melakukan penelitian dan menganalisa dengan cara memahami, menerangkan pasal-perpasal secara jelas, terperinci, dan sistematis.. Penelitian ini menggunakan pendekatan perundanganundangan yaitu pendekatan yang dilakukan dengan menelaah semua undang-undang dan 
regulasi yang bersangkut paut dengan isu hukum yang ditangani (Peter Mahmud Marzuki, 2015:24). Bahan hokum yang digunakan adalah bahan hokum primer, bahan hokum sekunder dan bahan hokum tertier. Teknik pengumpulan bahan hukum yang mendukung dan berkaitan dengan pemaparan penelitian ini adalah studi dokumen (studi kepustakaan). Teknik analis yang digunakan adalah deskriptif-analis yaitu uraian apa adanya terhadap suatu kondisi atau posisi dari proposisi-proposisi hukum atau non-hukum (Peter Mahmud Marzuki, 2015:21)

\section{Hasil Penelitian dan Pembahasan}

Undang-Undang Nomor 1 Tahun 1974 dibentuk dalam rangka mewujudkan unifikasi hukum perkawinan yang berlaku untuk semua warga Negara, serta kepastian hukum undangundang ini bertujuan untuk menjamin terwujudnya kesejahteraan yang lebih mendalam sebab perkawinannya didasarkan kepada keyakinan dan perkawinan tersebut juga harus dicatat sehingga menjamin kepastian hukum untuk mendapatkan hak (Wienarsih Imam Subekti dan Sri Soesilowati Mahdi, 2005:43).

Melalui unsur-unsur yang diuraikan pada pengertian perkawinan menurut UndangUndang Nomor 1 Tahun 1974 dapat disimpulkan bahwa konsep perkawinan menurut UndangUndang Nomor 1 Tahun 1974 berbeda dengan konsep perkawinan menurut KUHPerdata. Undang-Undang perkawinan memandang perkawinan bukan hanya sekedar hubungan keperdataan melainkan juga ikatan suci yang didasarkan oleh agama. Hal ini sesuai falsafah Pancasila yang menempatkan ajara Ketuhanan Ynag Maha Esa di atas segala-galanya (Hilman Hadikusuma, 2003:7). Undang-Undang Nomor 1 Tahun 1974 menempatkan agama sebagai unsur yang sangat penting dalam perkawinan. Sebuah perkawinan adalah sah apabila syaratsyarat atau ketentuan dalam hukum agama dan kepercayaannya masing-masing terpenuhi. Hal tersebut terdapat dalam Pasal 2 Undang-Undang Nomor 1 Tahun 1974. Dari rumusan Pasal 2 ayat (1) Undang-Undang Perkawinan tersebut juga dapat disimpulkan apabila suatu perkawinan dilakukan tidak menurut hukum agama dan kepercayaan masing-masing atau ada salah satu larangan perkawinan yang dilanggar maka perkawinan itu tidak sah.

Menurut Islam perkawinan dapat dikatakan sah apabila memenuhi rukun, syarat dan tidak melanggar larangan perkawinan sebagai yang ditentukan oleh syariat (Asmin, 1986: 29). Sehingga dalam hukum Islam rukun dan syarat-syarat perkawinan wajib dipenuhi. Kedua calon mempelai harus beragama Islam.

Menurut agama Katholik, pernikahan yang sah adalah pernikahan yang dilakukan, diteguhkan dan diberkati oleh pejabat gereja yang dihadiri oleh dua orang saksi yang telah memenuhi syarat-syarat pernikahan.

Agama Protestan juga mengatur hal yang sama yaitu mengatur ketentuan perkawinan beda agama dengan kesediaan pihak bukan Protestan untuk menikah di gereja dan mendidik anaknya secara Kristen.

Sahnya perkawinan menurut agama Hindu adalah bilamana dilakukan menurut hukum dan tata cara agam Hindu,yang diatur oleh Dharma (agama) dan harus tunduk pada agama. Bila suatu perkawinan tidak dilakukan menurut hukum agama, maka akibatnya bahwa segala akibat hukum yang timbul dari perkawinan tersebut tidak diakui sah oleh agama (Asmin, 1986: 47). 
Syarat-syarat perkawinan menurut agama Budha adalah kedua mempelai harus saling menyetujui dan cinta mencintai, umur kedua mempelai adalah minimal 21 tahun, diantara keduanya tidak ada hubungan darah atau hubungan susuan dan tidak terikat tali perkawinan dengan orang lain (Hilman Hadikusuma, 2003: 32). Sehingga perkawinan menurut agama Budha harus sama-sama yakin kepada Tri Ratna.

Sebagaimana dengan agama-agama lain yang diakui di Indonesia, maka sebagian orang yang menganut agama Khonghucu dalam melaksanakan perkawinan didasarkan pada ketentuan agamanya sendiri. Adapun ketentuan tersebut adalah dua calon yang akan melangsungkan perkawinan harus datang kepada pihak terkait (pemuka agama) yang akan memberkati mereka atau mengantarkan kedua mempelai pada upacara Liep Gwan (peneguhan) pernikahan di depan altar Thian dan nabi Khonghucu.

Setiap agama tidak bisa mengesahkan perkawinan beda agama, karena semua agama menginginkan umatnya untuk menikah dengan yang seagama dan untuk menjaga kesucian agama tersebut, maka dapat disimpulkan bahwa perkawinan beda agama menurut UndangUndang Perkawinan adalah perkawinan yang tidak sah, maka dilakukan penghindaran terhadap hukum yang seharusnya berlaku atau dapat dikatakan sebagai tindakan penyelundupan hukum, karena pelaku penyelundupan tersebut menghendaki untuk tidak berlakunya suatu sistem hukum karena akan menimbulkan akibat hukum yang tidak mereka inginkan. Berdasarkan beberapa contoh tindakan penyelundupan hukum perkawinan diatas, perlu adanya suatu ketegasan mengenai tindakan pemerintah dalam menangani kasus penyelundupan hukum ini. Dalam hukum perdata internasional dikenal konsep/teori vested right dimana suatu negara hendaklah mengakui atau menghormati hak-hak yang telah diperoleh seseorang berdasarkan kaidah hukum asing, namun penerapan konsep ini pun dimungkinkan bertabrakan dengan konsep ketertiban umum suatu negara.

Perkawinan campuran yang dimaksud dalam Undang-Undang Perkawinan adalah perkawinan antara dua orang yang tunduk pada hukum yang berlainan, karena perbedaan kewarganegaraan dan salah satu pihak berkewarganegaraan Indonesia. Jika perkawinan tersebut menyangkut juga perbedaan agama diantara para pihak, maka pengaturannya dikembalikan kepada hukum dimana perkawinan itu dilakukan, namun terdapat pengecualian dalam Pasal tersebut, yakni perkawinan campuran dapat dilaksanakan asalkan tidak bertentangan dengan hukum yang ada di Indonesia bagi warga negara Indonesia. Berdasarkan hal tersebut, walaupun pernikahan dilaksanakan di negara yang membolehkan perkawinan beda keyakinan, namun jika hal itu dilaksanakan oleh warga negara Indonesia, tetap perkawinan itu tidak dapat disahkan.

Kantor catatan sipil merupakan lembaga yang berwenang untuk mencatatkan perkawinan yang dilaksanakan di luar negeri. Jika perkawinan telah dicatatkan, tentu perkawinan tersebut sudah memiliki legalitas. Kantor Catatan Sipil dalam hal ini hanya bertugas mencatatkan perkawinan yang telah disahkan oleh pengadilan negeri, sehingga tidak memiliki kewenangan untuk menolak mencatatkan perkawinan yang telah disahkan oleh pengadilan negeri. Hal ini berbeda dengan Kantor Urusan Agama, dimana pada lembaga ini berhak menolak mencatatkan perkawinan yang tidak sesuai dengan hukum positif.

Pada sistem Hukum Indonesia, perkawinan antar agama memang masih menimbulkan perdebatan, sehingga di dalam prakteknya sering terjadi dan untuk memudahkan pasangan tersebut 
kawin berdasarkan agama salah satu pihak. Namun kemudian setelah perkawinan disahkan, mereka kembali kepada keyakinannya masing-masing. Di samping itu terdapat juga pasangan yang melangsungkan perkawinan di luar negeri, baru kemudian didaftarkan di Indonesia.

Jarwo Yunu mengatakan bahwa ada dua cara dalam menyikapi perkawinan beda agama yaitu (Jarwo Yunu, 2005: 11):

1. Salah satu pihak dapat melakukan perpindahan agama, namun ini dapat berarti penyelundupan hukum, karena sesungguhnya yang terjadi adalah hanya menyiasati secara hukum ketentuan Undang-Undang Nomor 1 Tahun 1974 tentang Perkawinan. Namun setelah perkawinan berlangsung, masing-masing pihak kembali memeluk agamnya masing-masing. Cara ini sangat tidak disarankan.

2. Berdasarkan Putusan Mahkamah Agung Nomor 1400.K/Pdt/1986, Kantor Catatan Sipil diperkenankan untuk melangsungkan perkawinan beda agama. Kasus ini bermula dari perkawinan yang hendak dicatatkan oleh Ani Vonny Gani P (Perempuan Islam) dengan Petrus Hendrik Nelwan (Laki-laki Kristen). Dalam putusannya Mahkamah Agung menyatakan bahwa dengan pengajuan pencatatan pernikahan di Kantor Catatan Sipil, maka Vonny telah tidak menghiraukan peraturan agam Islam tentang perkawinan dan karenanya harus dianggap bahwa ia menginginkan agar perkawinannya tidak dilangsungkan menurut agama Islam. Dengan demikian mereka berstatus tidak beragama Islam, maka Kantor Catatan Sipil harus melangsungkan pencatatan perkawinan tersebut. Dengan demikian, perkawinan berbeda agama mungkin saja dapat dilangsungkan di Kantor Catatan Sipil. Sebagai dasar hukumnya adalah yurisprudensi putusan Mahkamah Agung Reg No 1400 K/Pdt/1986 yang mengabulkan permohonan antara kedua mempelai yang berbeda agama Islam dan Kristen. Dengan demikian harus ditafsirkan bahwa dengan mengajukan permohonan itu pemohon sudah tidak lagi menghiraukan status agamanya. Dalam keadaan demikian Kantor Catatan Sipil sebagai satu-satunya instansi yang ber wenang melangsungkan perkawinan bagi kedua calon suami istri non-Muslim, wajib menerima pemohon.

Unsur asing dalam suatu perkawinan terdapat pada Pasal 56 (1) dan (2) Undang-Undang Perkawinan yang menyebutkan bahwa perkawinan antar WNI di luar Indonesia adalah sah bila dilakukan menurut hukum yang berlaku di negara dimana perkawinan itu dilangsungkan dan bagi warganegara Indonesia tidak melanggar ketentuan Undang-Undang Perkawinan dan satu tahun setelah perkawinan diwajibkan adanya suatu pencatatan (Nur Asiah, 2015: 4). Syarat sah perkawinan dilakukan di luar negeri tersebut tercermin syarat materil dan syarat formil yang dapat menjadi penentu validasi perkawinan berdasarkan asas-asas hukum perdata internasional (Bayu Seto Hardjowahono, 2013: 275).

Syarat materil berdasar lex loci celebrationis, status personalitas dan asas yang menyatakan bahwa hukum materiil berdasarkan sistem hukum dari tempat dilangsungkan perkawinan (locus celebration) tanpa mengabaikan syarat perkawinan yang berlaku di dalam sistem hukum para pihak. Dengan demikian dalam pelaksanaan hukum tetap mengacu pada dua sistem hukum yang melekat pada para pihak. Sedangkan syarat formil perkawinan ditentukan dengan asas locus regit actumyakni berdasarkan hukum tempat dilangsungkannya perkawinan (lex loci celebration).Pasal 56 Undang-Undang Perkawinan menyebutkan "bilamana dilakukan menurut hukum yang berlaku di negara dimana perkawinan itu dilangsungkan". 
Pada dasarnya pelaksanaan perkawinan di luar negeri oleh WNI yang berbeda agama merupakan bentuk usaha mencari keabsahan perkawinannya, dimana dalam hukum perdata internasional berlaku asas vested right atau asas hak-hak yang diperoleh. Istilah hak-hak yang diperoleh (vested rights) sering kali disebut dengan rights and obligations created abroadatau hak dan kewajiban hukum yang terbit berdasarkan hukum asing. Asas ini erat kaitannya dengan pengakuan terhadap apa yang telah dimiliki oleh, atau yang telah menjadi hak, atau yang telah melekat secara hukum pada suatu subjek hukum.

Hak dan kewajiban hukum yang telah diperoleh seseorang berdasarkan suatu kaidah hukum haruslah dihormati oleh siapa saja, termasuk oleh lex fori (Hukum sang hakim), kecuali jika pengakuan terhadap hak-hak semacam itu akan menimbulkan akibat-akibat yang bertentangan dengan ketertiban umum dari masyarakat. Pandangan atau asas ini memang berkembang pada masa memuncaknya pandangan hidup individualistik yang menganggap bahwa "hak milik" seseorang mempunyai kekuatan hukum yang mutlak sehingga perlu memperoleh perlindungan mutlak dimanapun dan terhadap apapun.

Sejalan pula dengan perkembangan tentang "hak milik yang berfungsi sosial", wawasan mengenai doktrin vested rights ini mengalami pergeseran pula dan orang cenderung untuk menganut ajaran ini secara terbatas (qualified). Pengertian vested rights dalam arti yang terbatas yaitu hak-hak yang dimiliki seseorang berdasarkan kaidah hukum asing dapat diakui selama pengakuan itu tidak bertentangan dengan ketertiban umum lex fori. Berdasarkan konsep hukum perdata internasional, penyelundupan hukum adalah perbuatan yang dilakukan di suatu negara asing dan diakui sah di negara asing itu. Perbuatan ini akan dapat dibatalkan oleh forum atau tidak diakui oleh forum jika perbuatan itu dilaksanakan di negara asing dengan tujuan untuk menghindarkan hukum lex fori yang akan melarang perbuatan semacam itu dilaksanakan di wilayah forum. Tujuan dari perbuatan ini adalah untuk menghindari akibat hukum yang tidak dikehendaki oleh para pihak atau untuk mewujudkan suatu akibat hukum yang dikehendakinya.

\section{Simpulan}

Perkawinan yang sah berdasarkan Pasal 2 ayat (1) Undang-Undang Nomor 1 Tahun 1974 Tentang Perkawinan adalah perkawinan yang dilaksanakan menurut agama dan kepercayaan masing-masing. Sehingga perkawinan dianggap sah jika menurut agama dan kepercayaan masing-masing calon suami istri tersebut juga sah. Berdasar penelitian yang telah dilakukan penulis dapat disimpulkan bahwa setiap agama tidak bisa mengesahkan perkawinan beda agama, karena semua agama menginginkan umatnya untuk menikah dengan yang seagama, yang bertujuan untuk menjaga keimanan individu agar tidak terpengaruh ajaran agama lain. Karena semua agama mensyaratkan calon suami istri harus satu agama, maka dilakukan penghindaran terhadap hukum yang seharusnya berlaku atau dapat dikatakan sebagai tindakan penyelundupan hukum, karena pelaku penyelundupan tersebut menghendaki untuk tidak berlakunya suatu sistem hukum karena akan menimbulkan akibat hukum yang tidak mereka inginkan, yaitu dengan melaksanakan perkawinan beda agama di luar negeri, meminta penetapan pengadilan, kawin menurut masing-masing agama dan tunduk sementara pada salah satu hukum agama. 


\section{E. Saran}

Pengaturan permasalahan perkawinan beda agama dirasa kurang tegas, karena dalam Undang-Undang Perkawinan tidak secara tegas dan jelas menyebutkan bahwa perkawinan beda agama dilarang. Undang-undang perkawinan hanya mengatur mengenai sahnya perkawinan dimana sahnya suatu perkawinan harus dilakukan menurut hukum masing-masing agama dan kepercayaan. Dan juga pada Pasal 8 huruf f mengenai larangan perkawinan beda agama hanya menyetakan bahwa perkawinan dilarang antara dua orang yang mempunyai hubungan yang oleh agamanya atau peraturan lain yang berlaku dilarang. Dalam UndangUndang Perkawinan tidak ada satu pasal pun yang menyebutkan secara tegas bahwa perkawinan beda agama dilarang. Oleh karena itu sebaiknya masalah perkawinan beda agama diatur oleh DPR bersama pemerintah secara tegas dan jelas di dalam Undang-Undang Perkawinan dengan cara melakukan perubahan pada Undang-Undang Perkawinan beda agama dalam satu pasal.

\section{F. Daftar Pustaka}

Agustina Nurhayati. 2011. Pernikahan Dalam Perpektif Al Quran. Jurnal ASAS. Volume 3 Nomor 1.

Anggreini Carolina Palandi. 2013. Analisa Yuridis Perkawinan Beda Agama Di Indonesia. Lex Privatum. Volume 1 Nomor 2.

Asmin. Status Perkawinan Antar Agama Ditinjau Dari Undang-Undang Perkawinan Nomor 1/1974. Cet 1. Jakarta: Dian Rakyat, 1986.

Hardjowahono, Bayu Seto. Dasar-Dasar Hukum Perdata Internasional. Jakarta: Citra Aditya Bakti, 2013.

Hilman Hadikusuma. Hukum Perkawinan Indonesia menurut Perundangan, Hukum Adat, Hukum Agama. Cet 2. Bandung: Mandar Maju, 2003.

Jarwo Yunu. Aspek Perkawinan Beda Agama di Indonesia. Jakarta, CV. Insani, 2005

Nur Asiah. 2015. Kajian Hukum Terhadap Perkawinan Beda Agama Menurut Undang-Undang Perkawinan Dan Hukum Islam. Jurnal Hukum Samudra Keadilan. Volume 10 Nomor 2.

Peter Mahmud Marzuki. Penelitian Hukum. Jakarta: Kencana Prenada Media Group, 2011.

Rani Dwisaptani, Setiawan dan Jenny Lukito. 2008. Konversi Agama dalam Kehidupan Pernikahan. Humaniora. Volume 20 Nomor 3.

Rusli dan R. Tama. Perkawinan Antar Agama dan Masalahnya.Bandung: Pionir Jaya, 1986

Subekti, Wienarsih Imam dan Sri Soesilowati Mahdi. Hukum Perorangan Dan Kekeluargaan Perdata Barat. Cet 1. Jakarta: Gitama Jaya, 2005.

Wahyono Darmabrata dan Surini Ahlan Sjarif. Hukum Perkawinan dan Keluarga di Indonesia. Cet 2. Jakarta: Badan Penerbit Fakultas Hukum Universitas Indonesia, 2004 